\title{
The Crisis and the Changing Face of the State
}

\author{
By Andrea Borghini*
}

\begin{abstract}
This paper provides a broad reflection on the transformation of State power in times of crisis. Starting from the extensive sociological literature that has been produced on this topic, this paper aims to answer questions such as: how does the crisis affect and (if at all) change the role of the State? Is a crisis an opportunity for the State to recover some of its historical powers? Or does it result in its definitive decline? Which kind of State emerges, during a time of crisis, in southern European countries? In order to answer these questions, this paper introduces the notion of the State as conceptualised in the sociology of Pierre Bourdieu. Based on this strong categorical perspective, this paper discusses and takes a stand between the two "parties", i.e., those that advocate the end of the State and those who demand a greater presence of this political institution in times of crisis. What emerges, in our analysis, is a different perspective of the State: a State unlocked from the nation and outside of a territorial trap, a State as a flexible and adaptable construction, not necessarily a coherent, unitary and autonomous actor. The paper ends with some reflections on the concept of crisis.
\end{abstract}

Keywords: Bourdieu, Crisis, Cultural turn, Society, State.

\section{Introduction}

The relationship between Crisis and the State is historically ambivalent. While it is true that the State is currently in crisis, it is just as true that the notion of Crisis has accompanied the State, the political category of modernity, ever since its birth. Indeed, the State emerged in the aftermath of a historical crisis, that which put an end to the religious wars and saw the uprising of two great institutions, the Papacy and the Empire. With the end of the Thirty Years' War and the Peace of Westphalia which gave rise to the modern map of the European states, the State obtained the monopoly of the "political" (Schmitt 1995).

The Nation-State changed form over time, seeing its secondary characteristics (Poggi 1990) changing and assuming a range of variations, which we can define as an internal crises: there is a shift from the absolute State to the liberal democratic State, and then, in some cases, to the totalitarian State. This means that there is now a well-established form of the State, based on the territory-populationsovereignty triad, but that some of these characteristics or their relations with other aspects (citizenship, the nation, civil society) change.

The State, which grew between the XIX and XX century (Le Galès and King 2011) ${ }^{1}$, became the most widespread political form in the world, also due

\footnotetext{
* Associate Professor, University of Pisa, Italy.

1 "The twentieth century is the century of the growth of the State's capacity for intervention, which is manifested in multiple domains and in increasingly specific ways, which the Italian Weberian sociologist Gianfranco Poggi calls the cycle of the State. The contemporary State now accounts for around 45\% of GDP in the large countries specified. This growth has translated
} 
to its export with arms into non-European countries. In the mid-1970s, the State entered a phase of crisis, although some particularly attentive authors saw these signs as early as the 1950s (Arendt 1951).

The current crisis, representing the most serious crisis that the Nation-State has experienced since its founding, and which has substantially altered many roles and functions, is turning out to be a profound crisis, but one that will not cause its demise - today we can affirm this with certainty (Le Galès and King $2011)^{2}$ - but rather open up the way for further transformations and developments.

In other words, with respect to the State, today's crisis should be considered by taking up the classic definition of crisis as an opportunity. In this regard, Bordoni notes the following:

"because it requires a change [the crisis] may be a re-birth after a break. This means separation, of course, but also opportunity of choice, of decision and therefore an occasion to express an opinion [...] that is, it is the factor that makes way for change, which prepares us for the future restructuring on new foundations" (Bauman and Bordoni 2015: 5).

Therefore, we need to orient our reflections with the awareness that if we need to speak of the end, it does not mean the end of the State tout court, but rather the end of a certain configuration of the State and a certain idea of the State; and that we are witnessing the emergence of different definitions and ideas of the State that have partly broken with the past.

In that sense, while literature on the State is quite extensive and varied, and obviously difficult to summarise, and after years of being characterised by a division between those sceptical that the State is coming to an end and those convinced of its decline, today it seems to rely on the same assumption: we should not be speaking of the end of the State, but rather of its crisis and transformation. In support of this affirmation, several research projects have been developed on this matter at an international level. To cite only a few, there has been the Research Group at the University of Bremen (TranState) or the Research Group organised by LSE ${ }^{3}$, etc.

Reading certain studies and hearing certain positions, it almost seems that the institution of the State still holds too much importance to think that we can rid ourselves of it. It almost seems that its hold on the collective imagination which someone once described as bad - Beck (2003): the iron grip of the state on social imagination - is turning out to be something to reflect upon and which

into public policies which regulate, change and structure society in its most varied and differentiated domains" (455).

2 "It seems like a long time ago when some celebrated (and others agonised about) its coming decline, deemed inevitable by many scholars" (458).

${ }^{3}$ About the Research Group by the University of Bremen, see the books Transformations of the State?, Cambridge, Cambridge University Press, 2005 and Transforming the golden age nation State?, Basingstoke, Palgrave Macmillan, 2007. About the LSE Crisis States Research Network, see the Report Meeting the Challenges of Crisis States (2012). 
also has positive aspects (Maier 2012) ${ }^{4}$, both due to the functions that the State tends to perform, for example, at a level of governance and power that has now become transnational, and due to the new roles that it tends to take on, as well as because of the historical characteristics that it has assumed and which today, in the so-called post-state phase or the Leviathan 2.0 phase, it seems to be possible to reconstruct with greater critical detachment.

Therefore, the crisis is important for the State for another reason as well: because it makes it possible to reveal aspects of State action and of its definition which, in turn, demonstrate the need for extremely important theoretical and historical revisions, in order to grasp the resistance and persistence of this institution and the capacities it has shown to adapt to new global political and economic scenarios.

One of the questions at the centre of our reflection (crisis as opportunity or as the decline of the State?) therefore finds an articulated response: a crisis can be a factor for reform, an occasion for the revival of the State (Delwaide 2011), or at least some of its aspects. It can help us better understand the nature of that institution. While the crisis marks the decline of certain State functions (single centre of political power, guarantor of economic nationalism), in other ways it leads us to discover other functions of the State and to fix our attention on theoretical aspects that until now have remained in the background.

In that sense, in recent years, alongside empirical research, some of which is cited above, theoretical reflections have emerged in the literature meant to question the genesis of the State, the functions it performs and its outlooks. At times these appear to be complementary, and at times in conflict.

\section{The Perspective of Pierre Bourdieu}

One of the most interesting perspectives is that offered by sociologist Pierre Bourdieu.

Although the topic of the State occupied the French thinker continuously only in his later years, in some ways it seems to summarise his entire theoretical and methodological system.

It is not possible to exhaustively present here the entire development of the Bourdesian reflection on the State, rather we will limit to mentioning its main defining features.

Bourdieu's notion of the State can be substantially drawn from the volume that collects the courses he taught on this topic at the College de France (2012), and from certain essays and articles he wrote in the second part of his intellectual career.

Even the definition that Bourdieu chooses is emblematic of his particular relationship with the classics:

\footnotetext{
4 "States protected vulnerable individuals and communities. They provided the legal carapace for the soft bodied creature of humanity, lying exposed to the cruel and rapacious or even just profit-seeking and zealous. Power and violence don't disappear when states are feeble; rather they are exercised without the restraint of law" (Maier 2012: 306).
} 
"the State is something to be determined (X) which successfully claims the monopoly of the legitimate use of physical and symbolic violence over a definite territory and over the totality of the corresponding population" (Bourdieu et al. 1994: 3).

The idea of symbolic violence is an only apparently marginal addition, which in reality revolutionises the classic Weberian definition. This is because, later on, Bourdieu will say that it is symbolic violence which enables physical violence, as well as because it opens up a new line of research about the State, from a historical-genealogical perspective, which no longer studies coercion in and of itself, but rather the historical and cognitive grounds of the particular legitimacy on the basis of which the State exercises coercion.

Bourdieu therefore insists on a genealogical vision of the State, the only one capable of enabling the scientific observer to get round the risk of using the language of the State to speak about the State, thereby making the reflection critically unproductive:

"to endeavour to think the state is to take the risk of taking over (or being taken over by) a thought of the state, i.e. of applying to the state categories of thought produced and guaranteed by the state and hence to misrecognize its most profound truth $[\ldots]$ one of the major powers of the state is to produce and impose (especially through the school system) categories of thought that we spontaneously apply to all things aspects of the social world-including the state itself" (Bourdieu et al. 1994: 1).

In that sense, Bourdieu has a strong tendency to overcome Marxist positions (when for example he claims that Marxists tell us what the State does, but they are unable to tell us what the State is) and to offer an anti-substantialist reading of the State, which is instead connected with relational sociology, typical of his innovative theoretical and empirical approach.

In other words, the State is presented as a collective belief, as a shared principle on the sense of the social world, for how we perceive it, in highly differentiated societies; as an instituting institution that progressively aspires to obtain the monopoly of the universal. When speaking of how the State operates, through acts of the State, this reveals its nature as a well-grounded illusion. Bourdieu wonders about the mystery of the ministry (ministry in the sense that it wields over a person a power that is not its own) or the ways in which the State presents itself to the general public as the holder of the monopoly over the right to consecration and delegation.

The result is an identikit of the State which is partially different from what we are used to, and which lies within a very recent tradition of thought, of which Bourdieu is one of the pioneers, which attempts to overcome the classical literature belonging to the "work of Norbert Elias or the comparative macrosociology of Charles Tilly, or even Weberian sociology. Indeed, these conceptualisations now show their limits" (Le Galès and King 2011: 452). The symbolic aspect of power is underscored, through the notions of symbolic 
violence, the symbolic capital over which the State holds a monopoly. Emphasis is also placed on the role of State practices (acts of the State), which create a singular connection with the reflections of an author like Popitz (1992) with regard to processes for the institutionalisation of power. Durkheim with his The Elementary Forms of Religious Life (2008) is taken up once again to make the State through "the thought of the State", a notion which we view as being quite close to the methodological nationalism of U. Beck (2003) - the guarantor of logical and moral conformism, for example through the control of public time; or its placement at the apex of collective meaning-making, of the production of collective beliefs regarding the social world.

It is clear that this is a very ambitious an risky field of research (in many instances Bourdieu does not conceal these risks) which also presents contradictions and sows doubt - for example, it is not completely clear whether the State is a substance, a Deus absconditus, or a field - and this is a perspective that prefers to focus on the reasons for conformism and the legitimation of power, instead of on constriction.

Aside from the debates, some heated, which each writer spawns, with Bourdieu the sociology of the State can no longer be the same and his perspective of the State introduces radical innovating elements in the revival of the debate, which we are seeing today, about this institution.

The Bourdesian perspective brings us back to the cognitive dimension of State power, to symbolic forms of power, which are even more important than physical forms: symbolic power, symbolic violence, collective belief, etc.

In the current period, in which classic institutional categories are being overcome, characterised by the disconnection between social space and political institutions, the polycentrism of powers, the Bourdesian approach has the value of bringing daily life back to the centre of inquiry, as a privileged place where we can discover the dramas of power and State action. It is positioned as a privileged perspective from which to study power, for example in a dialectic to be (re)discovered with Foucault.

\section{Convergent Perspectives?}

There is another element that makes Bourdieu's notion of the State particularly interesting: it is the harmonies that can be identified with other writers who either reference Bourdieu or work autonomously to overcome certain theoretical positions and innovate upon the panorama of studies on the State, often with a pragmatic motivation: understanding what that institution has become today, why it resists attempts to overcome it and the forms it takes on.

We refer to the works of Mann (1986) with the notion of infrastructural power, Steinmetz (1999), the first to sense the link between the State and Cultural studies, Chernilo (2007), who discusses "methodological nationalism" and highlights certain ambivalences associated with the nature of the State, Bevir and Rhodes (2010), who see the State as a cultural practice, and Jessop (2016). 
who, in a recent publication, revisits the idea of the State and proposes a new reading of it, that of the State as a social relation, to name just a few.

These perspectives, which cannot be aggregated within an organic paradigm, help us understand several things:

- They offer an explanation of the capacity of the State to adapt to global logics, for example by dissolving its ontological dimension into a relational dimension (Jessop 2016);

- They bring to light certain new basic features: for example, the stateterritory split, flexibility, ambivalence, separation between the state and the nation (Bevir and Rhodes 2010, Brenner 1999);

- They introduce an aspect yet to be investigated linked to the symbolic functions of State power which until this time have remained latent (Steinmetz 1999);

- They attempt to overcome the classic state-society dialectic (wellgrounded fictions which have now become old, also according to Steinmetz 1999).

In our view, these authors and their approaches constitute a powerful tool for interpreting the trajectory of the State and they revitalise a debate which for quite some time, especially after the eruption of globalisation, seemed to languish in antithetical, inflexible and fruitless positions. Both those in favour of globalisation, who historically see the State as an enemy of market forces and cheer for globalisation as the hangman of the State or at least as a process that has reduced it to an ancillary role, and those according to whom the State will never become extinct, as it is closely allied with processes of globalisation, seem to share the same prejudice about the State, which is seen as a monolith, an actor which is at times autonomous, but also mechanical, at times the slave of the market and at times an ally.

Let's look at a concrete example: in a recent publication, Bauman and Bordoni (2015) speak of the crisis of the State as a crisis of the relationship between power and politics, as the State's inability to meet the demands of the citizens and face the economic crisis. Compared to the crisis of 1929 in which the Keynesian state reacted by increasing public policies and investing, today the States are too indebted to invest and they "limit themselves" to cutting, and these cuts are paid for in terms of costs by the citizens. Although the two writers' analysis appears to be reasonable when it goes through the reinforcement of statehood in the 1900s through, for example, the construction of social policies, the diagnosis appears to be less convincing with respect to the State's impotence, which has grown progressively from the 1970s onward, and has been generated substantially by the separation between politics and power (States continue to be political entities, but power has shifted elsewhere, to large multinational companies or global organisations), as the pessimism of these writers derives from their awareness of the impossibility for the State to act as it once did. It almost seems like they share the prejudice common to many of those who remain linked to a paradigm of the State that evidently has had its day, but the 
effort of academics and policymakers today is to innovate upon the panorama, not irrespective of the State, but by going back to its definition and focusing on a less uniform and monolithic view of its nature and its action. Indeed, today the State acts in any event - look at the case of Europe, or of other non-western scenarios. The issue is to understand whether this is a rear-guard action - for example, in the management of the migrant issue - or a metamorphosis under way. From the scientific perspective, wouldn't it be more useful to underscore the power-politics divide as well as the dialectic between material power and symbolic power that is instead still alive and well? ${ }^{5}$. It almost seems like the writers' bet on a monolithic State prevents them from understanding the ambivalences connected to the State while incorporating, for example, Castel (2004) with his contribution of some time ago, in which the sociologist traces the State's intrinsic ambivalence back to its historical origins. In this regard, with respect to a hot topic like security, on which many States are betting their very survival, the French sociologist first of all affirms that the problem of security-insecurity is not a modern one; it was born in a certain sense with the rise of the liberal State, and goes back to that incessant struggle between individual freedom and State protection. What we are living through today, in terms of expectations towards the security-providing State, are merely escape hatches which bring about nothing, and which avoid the problem. The call to the State for increased security in reality conceals a need for the State tout court and of its multi-secular policy of defence of individual safety:

"the individual demands that the state protect him [...] so the request of state appears truly much stronger in modern society than in previous ones [...]. Pressure is exerted, today, only on the State, except then to criticize it for being too intrusive. But if we want to be a State of laws, then this attempt to reach total protection can only disappoint, since total security is not compatible with absolute respect of the legal forms" (Castel 2004: 35).

And later on he notes:

"the contemporary individual has been deeply forged by state regulations. He is unable to [...] stand on his feet by himself, since it is as if he has been reduced to putty by the collective systems of security set up by the social state. Unless one wants to exalt a return to a state of nature, in other words a state of total insecurity, bringing into question forms of protection cannot lead to their suppression, but rather to their redistribution in the new conjuncture" (Castel 2004: 35).

Castel therefore concludes that the topic is more complex, and that the search for absolute security is in conflict with the notions forming the basis of a state

\footnotetext{
${ }^{5}$ I refer to those economic, environmental and terrorist crises, which have occurred with a certain frequency in recent years, in which we demand more State, as it is seen as protection from events now deemed incontrollable which directly or indirectly impact our countries.
} 
of laws, and risks transforming itself into a security-driven impulse that elects certain individuals or already-marginalized social clusters as scapegoats.

These two brief passages, taken from a recent publication on the State show visions that are, in a certain sense, opposites: on one hand the traditional view of the State as the only guide of society, and on the other hand the historical contradictions, intrinsic in the nature of the State, which can be found, for example, within the dialectic between the State and the individual.

Both readings converge upon one point: it is necessary "to return to the State", at least in terms of bringing its definition and its nature back into the realm of public debate.

\section{Conclusion}

Therefore, the merit of a renewed debate underlying the sociology of the State lies precisely in freeing the debate itself - although with all of the required precautions: we are not speaking of repudiating ones faith to embrace anotherfrom sterile contrasts, born of ways of thinking that are strongly anchored in tradition, and pushing into the global scene that has changed so radically with respect to the past methods of interpretation that are useful for understanding certain processes which are otherwise incomprehensible. The same Le Galès we have already referred to, notes in a very dense introduction to an essay on the State in the Revue française de Sociologie how the State shows undoubted capacity to recompose its action "by highlighting the logics of its vertical and horizontal expansion, the blurring of borders and the muddle of networks" (Le Galès and King 2011: 461), and how there are multiple lines of research that are developed which are oriented towards delinking the State from the territory, from the nation, towards understanding its capacity to adapt in the context of globalisation, beyond the contrasting views which see it as an institution that is either a slave to its capital or that is totally autonomous from it. Le Galès prefers to speak of a path:

"the processes of extending the market sphere, of globalisation and of financialisation destroy the State's capacity to control, regulate and sanction economic actors. To the contrary, these processes increase interdependencies between the States; they exacerbate conflicts between the actors of capitalism and the States" (Le Galès and King 2011: 467).

In addition, these lines of research revitalise the debate in this area and generate multiple empirical studies, as well as a broad debate on the functions of the State and on the various definitions that may be proposed (culturalist, constructivist, etc.).

Today, views of the State seem to be free of ideological veils and fitting to understand the State in its genesis, in its historicity, making it possible to follow its trajectories of development, based on historical and political contexts. 
We have tried to respond to some of our initial questions: the crisis can be an opportunity for the State, in terms of rethinking its conceptual architecture, and in terms of its roles and functions in the global landscape.

In particular on the conceptual level, the crisis frees up a series of perspectives, amongst which the Bourdesian appears to be particularly useful and heuristically fertile.

A question that is certainly not secondary remains before us: in what practical terms can these theories help us understand the concrete processes of stateless and stateness, for example in Europe or in southern Europe?

We can answer this question in two ways: practically and theoretically. From the practical point of view, we can look at specific trends, and then we can cite empirical studies which, based on the theoretical framework we have set up, are developed to grasp State trends on the field (Le Galès and King 2011). We can cite the studies of Jessop who reveals the difficulties that the traditional theory encounters when it compares the State and Globalisation, when both are understood as organic, unitary actors. Indeed, the sociologist notes on one hand how Globalisation

"is not a single causal mechanism with a universal, unitary logic. It comprises a hypercomplex, continuously evolving result of many events, processes, and transformations - a result that is multicentric, multiscalar, multitemporal, and multiform" (Jessop 2016: 191)

and, on the other, how "a search for easy generalization leads to neglect of the variety of state forms and political regimes that might be affected by globalization" (Jessop 2016: 192), as well as the different responses that each State or each group of States presents depending on their level of involvement in the world market:

"States should not be seen as somehow set apart from their respective economies, as if they existed in separate spheres and had only external relations with each other. On the contrary, normal States are, typically, heavily involved [...] and in many respects, in shaping the institutions and practices that constitute the economy" (Jessop 2016: 192).

This means that it is impossible to think about building a unique model of State conduct in the economic field.

If instead we take a closer look at the recent economic crisis, and at the European context, a dominant type of State emerges which Jessop defines as the austerity state, "embedded in a political system (polity) that institutionalizes a permanent politics of austerity" (Jessop 2016: 236).

The theoretical level, the second response to the previous question, and which moreover we have privileged in our reflection, constitutes a level for the recomposition of multiple empirical responses to the underlying question: in a reciprocal reference between theory and practice, investigations in the field require theoretical revisions; and in turn these theoretical revisions help define a model of the State that is partly different from the traditional versions in a 
circulation: a State which is defined as a complex institutional assemblage and a site of political practices "which seek to deploy its various institutions and capacities for specific purposes" (Jessop 2016: 246); a model that presupposes the renouncement of the idea that the State has a core made of "unitary, coherent ensemble of agency" (Jessop 2016: 247); and that the State is historically considered to be a political form endowed with peculiar characteristics, but that its life takes place within the social environment (of society) and therefore that the power of the State and its exercise are always conditional and relational.

One last mention of the theme of the crisis: also here, by conducting a historical review that relies on some classic thinkers, it is possible to place back into the collective imagination a broader and more historically profound version of crisis which combats the flattening and homogenisation that the current notion has experienced. It is enough to think of the numerous social scientists that have grappled with the topic of crisis; for example, Koselleck (2006) offers a historical fresco of the complex intricacies binding the category of crisis to modernity, showing how the term assumed its current, everyday language meaning, especially in its economic sense. A sociologist like Wallerstein (1991) reveals how the capitalist mode of production produced a systemic crisis from which it is difficult to escape without positing particularly daring trajectories, straining our predictive capabilities. Lastly, Bourdieu (1998) reveals - in the neighbouring semantic field of "family" - how words can become watchwords which we obey without the awareness that this obedience does not take us away from the abyss of crisis, but contributes to deepening it and to increasing the social misery and the inequalities of our society.

Listening to the voices of the authors mentioned we discover a dual path. On one side, the "crisis" as a historically deep and polysemous concept, which to be addressed, it is even necessary to deal with hard sciences and revolutionise the epistemological framework of social sciences. On the other side, as modernity advances, the term "crisis" loses its breadth and its value. The concept of "crisis" loses its historical dignity and, precisely because of the economy of which it has become a prisoner, it presents itself as a crisis of indifferentiation, as a word now devoid of history. Under the noble and high version of the concept of "crisis" its poor and monotonous version is hidden, only able to repeat the mantra of austerity and prescribing behaviours that bring us closer to the abyss instead of moving us away from it.

The Italian author Barcellona focuses a good deal on this reductionism and its dangers and tries to offer solutions for getting out of the dead-end where humanity seems to have come:

"the theme of the economic and political crisis needs to be read as a social crisis of the connective tissue of society, whose main victims are the productive middle class and the working class: we need to understand the tendency toward the change of this social, psychological, and economic reality, transforming individual aspirations in collective resources capable of having a real effect" (Barcellona 2013: 113-4). 
However, apart from the possible solutions, we feel it would be difficult to restore the meaning that "crisis" once had, because the historical and social conditions we are living in, and the times we are going through, are profoundly poor. Nevertheless, it's necessary to struggle with the weapons of the word and the pen, because intelligence can hope to identify the causes that led to the impoverishment of the current notion of crisis only by drawing from history and knowledge, and it's from here that we may start again a process of returning to "crisis" the dignity of category it deserves, despite the difficulties of the times we are living in.

\section{References}

Arendt H (1951) The origins of totalitarianism. New York: Schocken Books.

Barcellona P (2013) Parolepotere [Words and Power]. Roma: Castelvecchi.

Bauman Z, Bordoni C (2015) Stato di Crisi [State of Crisis], Cambridge: Polity Press/ Torino: Einaudi.

Beck U (2003) La società cosmopolita. Prospettive dell'epoca postnazionale [The Cosmopolitan Society. Perspectives from the postnational age]. Bologna: Il Mulino.

Bevir M, Rhodes RAW (2010) The state as cultural practice. Oxford: Oxford University Press.

Bourdieu P, Wacquant L, Farage S (1994) Rethinking the State: Genesis and Structure of the Bureaucratic Field. Sociological Theory 12(4): 1-18.

Bourdieu P (1998) Practical reason. On the theory of action. Stanford: Stanford University Press.

Brenner N (1999) Beyond state-centrism? Space, territoriality, and geographical scale. Theory and Society 28(1): 39-78.

Castel R (2004) L'insicurezza sociale [The social insecurity]. Torino: Einaudi.

Chernilo D (2007) A social theory of the nation-state. London: Routledge.

Delwaide J (2001) The Return of the State? European Review 19(1): 69-91.

Durkheim É (2008) The elementary forms of religious life. Oxford: Oxford University Press.

Jessop B (2016) The state: past, present, future. Cambridge: Polity Press.

Koselleck Rh (2006) Crisis. Journal of the History of Ideas 67(2): 357-400.

Le Galès P, King D (2011) Sociologie de l'état en recomposition [Sociology of the State in Recomposition]. Revue française de Sociologie 52(3): 453-480.

LSE Crisis States Research Network (2012) Report Meeting the Challenges of Crisis States.

Maier ChS (2012) Leviathan 2.0. Inventing modern statehood. Cambridge (MA): The Belknap Press of Harvard University Press.

Mann M (1986) The autonomous power of the State: Its origins, mechanisms and results. In JA Hall (ed) States in History, 109-136. Oxford: Blackwell.

Poggi G (1990) The state: its nature, development and prospects. Cambridge: Polity Press. 
Popitz H (1992) Phänomene der Macht [Phenomena of Power]. New York: Columbia University Press/Tübingen: Mohr.

University of Bremen Research Group (2005) Transformations of the State? Cambridge: Cambridge University Press.

University of Bremen Research Group (2007) Transforming the golden age nation State? Basingstoke: Palgrave Macmillan.

Schmitt C (1995) The concept of the political. Chicago: The University of Chicago Press.

Steinmetz G (ed) (1999) State/Culture. State-formation after the cultural turn. Ithaca and London: Cornell University Press.

Wallerstein I (1991) Unthinking social science: The limits of nineteenth-century paradigms. Cambridge: Polity Press. 